\title{
Effect of stem - bark of Erythrophleum suaveolens (Guill. \& Perri.) saponin on fresh water snail (Lanistes lybicus) tissues
}

\author{
Akinpelu, B. A. ${ }^{1}$, Dare C. A. ${ }^{1}$, Adebesin F. I. ${ }^{1}$, Iwalewa E. O. $^{2}$ and Oyedapo 0. 0. ${ }^{1 *}$ \\ ${ }^{1}$ Department of Biochemistry, Faculty of Science, Obafemi Awolowo University, lle-lfe, Osun State, Nigeria. \\ ${ }^{2}$ Department of Phamacology, Faculty of Pharmacy, Obafemi Awolowo University, lle-lfe, Osun State, Nigeria.
}

Accepted 14 May, 2012

\begin{abstract}
The study investigated the activity of saponin from ethanolic extract of Erythrophleum suaveolens stem bark against freshwater snail, Lanistes lybicus. The crude saponin $(4 \mathrm{~g})$ was separated by silica gel using gradient elution with dichloromethane in methanol (100:0 to 0:100) followed by thin layer chromatography using precoated silica gel $60 F_{254}$. Fractionated saponins $(90: 10,80: 20$ and $70: 30)$ were employed for snail toxicity using fresh water snails, L. lybicus. The biochemical changes were evaluated in haemolymph, muscle, intestine and hepatopancreas of fresh water snails exposed to sublethal dose of fractionated saponins. Elevation of activities of acid and alkaline phosphatase in the intestine and hepatopancreas, haemolymph and total protein level were observed. The activity of acetylcholinesterase was inhibited in the haemolymph, muscle, hepatopancreas and intestine of the snails. The activity of saponin was observed to be dose dependent as mortality increased with relative increase in the saponin concentrations. The study provides considerable scope in exploiting local indigenous plant resources for control of fresh water snails and monitor water pollution.
\end{abstract}

Key words: Erythrophleum suaveolens, saponin, molluscicidal activity, Lanistes lybicus, pollution, hepatopancreas.

\section{INTRODUCTION}

The control of harmful fresh water snails through synthetic as well as plant extracts has been extensively studied by several investigators (Agarwal and Rastogi ., 1974). Many species of fresh water snails act as intermediate hosts of trematodes, parasitic worms causing endemic diseases such as schistosomiasis, filariasis, etc. (Aladesanmi, 2007), and as pests in overpopulated water or farm where they decimate a population of live plants (Anon, 2001). Different strategies have been used to control snail populations but biological control stands to be a better alternative to the chemical controls. Synthetic molluscicides have been widely used for the effective control of vector snails (Clarke et al., 1997). However, these molluscicides are considered toxic to non target

${ }^{*}$ Corresponding author. E-mail: ooyedapo@yahoo.co.uk. Tel: 08161329598. animals and may have long-term detrimental effects on the aquatic environment (WHO, 1985; Massoud and Habib, 2003).

The search of herbal preparations, that do not produce any adverse effects in the non-target organisms and which are easily biodegradable, remains a top research issue for scientists associated with alternative molluscicides control. Medicinal plants represent the oldest and most wide spread form of medication known to man and have become the focus of attention as source of molluscicidal agents, since they are less expensive and less hazardous to the environment compared to their synthetic counterparts (WHO, 1985).

The use of plant molluscicides has received increased interest, primarily because it could be an appropriate and inexpensive technology for snail control in endemic poor nations of the world (Aladesanmi, 2007).

Saponins extracted from many sources have been reported to exhibit molluscicidal properties; they include 
Phytolacca dodecandra (Lemma, 1970), Tetrapleura tetraptera (Leguminosae) (Adewunmi, 1984; 1991) and Balanite aegptica (Marston and Hostettmann, 1985).

Erythrophleum suaveolens is a perennial tree of about $30 \mathrm{~m}$ in height, slightly buttressed, often low-branching and producing a dense spreading crown. It is referred to by various names by natives. These include obo and erun (Yoruba), inyi (lgbo), baska (Hausa), aba (AkanAsante, Ghana), digpende (Bassari -Togo), teli (Koranko - Sierra Leone), etc. It is often referred to in English as sassy, sasswood, red water tree and ordeal tree (Burkill, 1985). Studies have shown that the plant Erythrophleum species are extremely toxic to livestock especially sheep and cow. In Savannah regions, the cattle herders are always very careful not to allow their animal to graze along the routes where the trees of these species are known to grow (Nwude, 1981; Nwude and Chineme, 1981).

In folk medicine, the stem bark decoction is used as emetic and purgative, as an anesthetic, anthelminitic, treatment of malaria, analgesic and disinfectant. The extracts are utilized in cases of skin disease, oedemas, gangrenous wound, rheumatism and arthritis. It is also reported to be used as poison or repellant against rodent, insects and some aquatic animals and also in tanning hides and as dye (Aiyegoro et al., 2007; Burkill, 1985; Dongmo et al., 2001)

As such, this study investigated and reported the activity of saponin from ethanolic extract of $E$. suaveolens stem bark for control of fresh water snails (Lanistes lybicus) and monitoring water pollution.

\section{MATERIALS AND METHODS}

\section{Plant materials}

Dried stem-barks of E. suaveolens (Guill. \& Perr.) were obtained from the Central Local Market (Oja Tuntun) in Ile-Ife, Osun State, Nigeria. The identification and authentication of the plant was done by Dr. H .C. Illoh, Department of Botany, Obafemi Awolowo University, Ile-Ife, Nigeria.

\section{Reagents and chemicals}

All the reagents used were of analytical grade and procured from British Drug House (BDH) Poole, U.K., Sigma Chemical Company, Louis, U.S.A., Fluka Chemical Company, USA and Pharmacia Fine Chemicals, Uppsala, Sweden. Silica gel $60 \mathrm{~F}_{254}$ precoated-plate (20 $\times 20 \mathrm{~cm}$ ) was a product of Alumgram, Germany. Silica gel 60 (50 to 200 mesh) was obtained from Lab. Tech. Chemicals, U.S. Aluminium Oxide was from Associated Chemical Enterprises, South Africa.

\section{Fresh water snails}

Adult fresh water snails ( $L$. lybicus) with mean length $2.3 \pm 0.2 \mathrm{~cm}$ and average weight of $39 \pm 2.0 \mathrm{~g}$ were collected from the gutters behind Department of Botany, Obafemi Awolowo University, Ile-Ife, Osun state, Nigeria. The snails were acclimatized in laboratory conditions for two weeks. They were kept in a plastic aquaria containing stream water at $25^{\circ} \mathrm{C}$ and fed with fresh leaves of Telfairia occidentalis and Talium triangularie.

\section{Isolation and fractionation of crude saponin}

Ethanolic extract of the stem bark of E. suaveolens was prepared according to the procedure described by Oyedapo and Amos (1997). Typically, powdered $(900 \mathrm{~g})$ dried stem bark was suspended in $4.2 \mathrm{~L}$ of $80 \%(\mathrm{v} / \mathrm{v})$ ethanol for $72 \mathrm{~h}$ at room temperature. The suspension was filtered through two layers of cheese-cloth. The extraction process was repeated several times until the extract became clear. The filtrates were combined and concentrated under reduced pressure on rotatory evaporator (Edward Vacuum Cooperation, Crawley, England) at $35^{\circ} \mathrm{C}$ to give a coffee brown residue which was stored in the dessicator until required for further processing.

Crude saponin mixture was isolated according to a procedure that was based on the methods described by Abdel-Gawad et al. (1999) and Wagner et al. (1984). The ethanolic extract $(10 \mathrm{~g})$ was washed twice with chloroform $(50 \mathrm{ml} \times 2)$ and, also twice with ethylacetate $(50 \mathrm{ml} \times 2)$. The residue was dissolved in $50 \%(\mathrm{v} / \mathrm{v})$ methanol. The water-methanol solution was extracted three times $(100 \times$ 3 ) with $n$ - butanol. On evaporation, a syrupy residue was obtained which was taken up in methanol $(50 \mathrm{ml}, 50 \% \mathrm{v} / \mathrm{v})$, followed by the addition of diethylether $(100 \mathrm{ml})$ to precipitate crude saponins. The precipitate was further purified by repeated dissolution in methanol $(50 \mathrm{ml} \times 5)$ and precipitation with diethylether $(50 \mathrm{ml} \times 5)$ until a cream light brown precipitate termed crude saponins was obtained.

The crude saponin was fractionated on silica gel (Kiesel gel 60; 60 to 200 mesh) column chromatography using gradient elution with mixture of dichloromethane in methanol (DCM: MeOH) 100:0 to $0: 100$ as described by Lin et al. (2008). Fractions were collected for each of the solvent mixtures and evaporated to dryness at $40^{\circ} \mathrm{C}$ on rotatory evaporator to give various fractions. The active fractions were subjected to thin layer chromatography on precoated silica gel $60 \mathrm{~F}_{254}$ plates $\mathrm{DCM}$ : $\mathrm{MeOH}$ (95:5) as mobile phase. The chromatograms were sprayed with spraying reagent $(0.5 \% \mathrm{p}$-anisaldehyde in $\mathrm{MeOH}$ : acetic acid: conc. $\left.\mathrm{H}_{2} \mathrm{SO}_{4}(17: 2: 1 \mathrm{v} / \mathrm{v} / \mathrm{v})\right)$ followed by incubation at $110^{\circ} \mathrm{C}$ for $3 \mathrm{~min}$ and visualized with iodine vapour.

\section{Molluscicidal activity assay}

\section{Toxicity studies of the fractionated saponin mixture}

The fresh water snails were treated with saponins, using the guideline for evaluation of molluscicidal potency of extracts. Six aquaria of five (5) snails each with an average weight of $39 \pm 2 \mathrm{~g}$ in each aquarium were set up in duplicate using river water. The saponin mixtures $(10,20,3040$ and $50 \mu \mathrm{g} / \mathrm{ml}$ concentrations) were prepared using $\mathrm{DMSO} / \mathrm{H}_{2} \mathrm{O}, 1: 1(\mathrm{v} / \mathrm{v})$. Each of the concentrations was diluted with river water to make up $500 \mathrm{ml}$ in each aquarium. Mixture of $\mathrm{DMSO} / \mathrm{H}_{2} \mathrm{O}$ was applied to the sixth aquarium which served as the control. Period of $48 \mathrm{~h}$ exposure was allowed, followed by $48 \mathrm{~h}$ recovery period. Death of the snails was confirmed by lack of reaction to irritation of the foot, with a blunt wooden probe to elicit typical withdrawal movements. Control snails were subjected to the same condition. The $\mathrm{LD}_{50}$ was estimated using probit analysis (Finney, 1971).

\section{Collection and preparation of tissue homogenates}

The shells of the active snails were broken after $48 \mathrm{~h}$ recovery period in fresh water. The tissues were dissected using forceps and scissors. The muscle, hepatopancreas, haemolymph and intestine 
of each snail were collected separately. The combined haemolymph from each group was centrifuged on Bench Centrifuge Model 800D (Microfield Instrument England, UK) at $3000 \mathrm{rpm}$ for $10 \mathrm{~min}$ at room temperature. The supernatants were transferred into vials and kept wet-frozen in deep freezer (Royal Chest Freezer) until analyzed biochemically.

The homogenization of muscle, hepatopancreas and intestine was carried following the methods reported by Olagunju et al. (2000). The muscle, hepatopancreas and intestine were weighed. Each of the muscles (average weight of $1.2 \mathrm{~g}$ ) in each group was homogenized using $10 \mathrm{ml}$ of normal saline. The hepatopancreas per snail (average weight of $0.66 \mathrm{~g}$ ) in each group was homogenized using $5.0 \mathrm{ml}$ of normal saline. The intestine per snail (average weight of $1.5 \mathrm{~g}$ ) in each group was homogenized using 10 $\mathrm{ml}$ of normal saline. The homogenization was carried out using mortar and pestle aided with washed fine sand. The homogenates were centrifuged at $3000 \mathrm{rpm}$ for $10 \mathrm{~min}$. The supernatant in each tube was collected into labeled vials and kept in the deep-freezer until analyzed.

\section{Biochemical analyses of tissue homogenates}

The following biochemical analyses were carried out on the snail's haemolymph and tissue homogenates.

Estimation of total protein: The total protein concentrations were determined by simplified method for the quantitative assay of small amount of protein in biological material as described by Shacterk and Pollack (1973). Typically, $1.0 \mathrm{ml}$ of each of the homogenates was pipetted into clean test-tubes in triplicates, $1.0 \mathrm{ml}$ of alkaline copper reagent $\left(10 \% \quad \mathrm{Na}_{2} \mathrm{CO}_{3}, 0.1 \% \mathrm{~K}-\mathrm{Na}\right.$ tartarate and $0.05 \%$ $\mathrm{CuSO}_{4} .5 \mathrm{H}_{2} \mathrm{O}$ ) was added and mixed thoroughly. The mixtures were left to stand undisturbed for $10 \mathrm{~min}$ at $25^{\circ} \mathrm{C}$. Then, $4.0 \mathrm{ml}$ Folin-Ciocalteu's Phenol reagent (1:10 dilution) was added forcibly and rapidly. The blank was also prepared using distilled water instead of the homogenates. The mixture was then incubated at $55^{\circ} \mathrm{C}$ for $5 \mathrm{~min}$, removed and cooled under running water. The absorbance was read at $650 \mathrm{~nm}$ against the blank. The protein concentrations were calculated using the expression:

Concentration of protein $(\mathrm{g} / \mathrm{dl})=$ Abs. of sample/ Abs. of standard $x \mathrm{df} \times$ concentration of standard protein.

Where, Abs is absorbance at $650 \mathrm{~nm}$ and df is dilution factor.

Assay of acetylcholinesterase activity: The assay was carried out by a procedure that was based on the method of Ellman et al. (1961) with slight modifications. The reaction mixtures consisted of $25 \mu \mathrm{l}$ of haemolymph and $50 \mu \mathrm{l}$ each of the other homogenates in triplicates. Then, $50 \mu \mathrm{l}$ (5, 5'-dithiobis-2-nitrobenzoic acid (DNTB) in $5 \mathrm{mM}$ sodium phosphate buffer, $\mathrm{pH} 8.0$, containing $17.74 \mathrm{mM}$ $\mathrm{NaHCO}_{3}$ ) was added followed by $1.45 \mathrm{ml}$ of $5 \mathrm{mM}$ sodium phosphate buffer, $\mathrm{pH}$ 8.0. The reaction mixtures were mixed properly and transferred into a cuvette followed by the addition of $1.45 \mathrm{ml}$ of $5 \mathrm{mM}$ sodium phosphate buffer, $\mathrm{pH}$ 8.0. The initial absorbance was read at $412 \mathrm{~nm}$ on SpectrumLab $752 \mathrm{~S}$ uv/vis spectrophotometer. The reaction was initiated by the addition of $50 \mu$ l substrate $(12.5$ $\mathrm{mM}$ acetylcholine iodide) and stirred. The absorbance was read at $30 \mathrm{~s}$ interval for $4 \mathrm{~min}$. The change in absorbance per time (slope) for each experimental data was determined. The activity of acetylcholinesterase was estimated using the following expression:

Enzyme activity ( $\mu \mathrm{mol} \mathrm{SH}$ hydrolyzed $\mathrm{min} / \mathrm{mg}$ protein) $=\Delta \mathrm{A} \times$ $\mathrm{TV} / \varepsilon_{\text {DTNB }} \times \ell \times \mathrm{SV}$,
Where $\Delta \mathrm{A}=$ change in absorbance $/ \mathrm{min} ; \mathrm{TV}=$ total volume of the assay; SV $=$ sample volume $(25 \mu \mathrm{l} / 50 \mu \mathrm{l}) ; \ell=$ path length of cuvette $(1 \mathrm{~cm}) ; \varepsilon_{\text {DTNB }}=$ molar extinction co-efficient of DTNB $(1.36 \times$ $\left.10^{4} \mathrm{M}^{-1} \mathrm{~cm}^{-1}\right)$.

Assay of alkaline and acid phosphatases: The assays of alkaline and acid phosphatases were carried out by the method described by Sanni and Van Etten (1978) as reported with slight modification by Oyedapo (1996). The reaction mixture contained $50 \mu \mathrm{l}$ haemolymph (or $50 \mu \mathrm{l}$ of muscle/intestine/ hepatopancreas homogenates) in triplicates and incubated at $37^{\circ} \mathrm{C}$ for $3 \mathrm{~min}$. The blank was similarly prepared using water instead of the liver homogenates or plasma samples. The reaction was initiated by the addition of $1.0 \mathrm{ml}$ of substrate (5 mM p-nitro phenyl phosphate, $\mathrm{Na}$ salt) in appropriate buffer. The reaction mixtures were incubated for additional $15 \mathrm{~min}$, followed by the addition of $2.0 \mathrm{ml} 0.02 \mathrm{M} \mathrm{NaOH}$ to terminate the reaction. The reaction mixtures were allowed to cool down to room temperature. The absorbance was read at $410 \mathrm{~nm}$ against the reagent blank. The activities of the phosphatases were calculated using the following expression:

$$
\frac{\text { Absorbance }}{\varepsilon \times 1} \times 10^{6} \times \frac{1}{\mathrm{t}} \times \frac{\mathrm{TV}}{\mathrm{SV}}
$$

Where $\varepsilon=$ molar extinction co-efficient $\left(1.88 \times 10^{4} \mathrm{M}^{-1} \mathrm{~cm}^{-1}\right) ; \mathrm{I}=$ path length of cuvette $(1.0 \mathrm{~cm})$; TV = total assay volume; $\mathrm{SV}=$ sample volume $(25 \mu \mathrm{l} / 50 \mu \mathrm{l})$ and $\mathrm{t}=$ incubation time $(15 \mathrm{~min})$

\section{Statistical analysis}

Data for the biochemical assays were expressed as mean \pm SEM. Statistical analysis was performed by one way ANOVA followed by Turkey-Kramer multiple comparison test to ascertain differences between treatment groups. All analysis was performed using GraphPad Instat 3 (Version 1.1, 2007).

\section{RESULTS}

There was no mortality recorded in the 0 to $30 \mu \mathrm{g} / \mathrm{ml}$ concentration, $60 \%$ mortality was recorded in the $40 \mu \mathrm{g} / \mathrm{ml}$ concentration while $100 \%$ mortality was recorded when $50 \mu \mathrm{g} / \mathrm{ml}$ was applied. Using Probit analysis, LD $_{50}$ was estimated to be $38.74 \mu \mathrm{g} / \mathrm{ml}$.

The effects of sub-lethal concentration of saponin fractions of $E$. suaveolens on total protein, acid phosphatase, alkaline phosphatase and acetylcholine esterase in the muscle, hepatopancreas, haemolymph and intestine of $L$. lybicus are summarized in the Table 1 . There was significant increase $(p \leq 0.05)$ in muscle and haemolymph total protein concentration. In intestine and hepatopancreas, alkaline phosphatase activities increased significantly ( $p$ $\leq 0.5$ ). It was noted further that acid phosphatase activity in the intestine and hepatopancreas increased and the increase was significant at $30 \mu \mathrm{g} / \mathrm{ml}$ only in hepatopancreas. In the haemolymph, the activity of the enzymes reduced significantly as saponin concentration increases. Moreover, acetylcholinesterase activity was significantly $(p \leq 0.05)$ inhibited in intestine, while the inhibition of the enzyme in the muscle, hepatopancreas, and Haemolymph were not statistically significant. 
Table 1. Changes in total protein concentration and enzyme activities in the haemolymph muscle, hepatopancreas and intestine of $L$. lybicus after $96 \mathrm{~h}$ of exposure to fractionated saponin mixture.

\begin{tabular}{|c|c|c|c|c|c|c|}
\hline Parameter & Tissue & Control & $10(\mu \mathrm{g} / \mathrm{ml})$ & $20(\mu \mathrm{g} / \mathrm{ml})$ & $30(\mu \mathrm{g} / \mathrm{ml})$ & $40(\mu \mathrm{g} / \mathrm{ml})$ \\
\hline \multirow{4}{*}{ Total protein $(\mathrm{mg} / \mathrm{dl})$} & Haemolymph & $0.561 \pm 0.004$ & $1.357 \pm 0.017^{*}$ & $1.324 \pm 0.002^{*}$ & $1.346 \pm 0.001^{*}$ & $1.346 \pm 0.001^{*}$ \\
\hline & Muscle & $0.121 \pm 0.028$ & $0.202 \pm 0.014^{*}$ & $0.214 \pm 0.019^{*}$ & $0.264 \pm 0.015^{\star}$ & $0.250 \pm 0.004^{*}$ \\
\hline & Hepatopancreas & $0.211 \pm 0.036$ & $0.262 \pm 0.014$ & $0.257 \pm 0.019$ & $0.297 \pm 0.015^{\star}$ & $0.293 \pm 0.004$ \\
\hline & Intestine & $1.341 \pm 0.031$ & $1.339 \pm 0.003$ & $1.351 \pm 0.004^{*}$ & $1.352 \pm 0.001$ & $0.894 \pm 0.006^{*}$ \\
\hline \multirow{4}{*}{$\begin{array}{l}\text { Alkaline phosphatase } \\
\text { ( } \mu \text { mole/min/mg } \\
\text { protein) }\end{array}$} & Haemolymph & $0.023 \pm 0.001$ & $0.022 \pm 0.001$ & $0.027 \pm 0.000^{*}$ & $0.016 \pm 0.000^{*}$ & $0.01 \pm 60.000^{*}$ \\
\hline & Muscle & $0.152 \pm 0.029$ & $0.059 \pm 0.010^{*}$ & $0.127 \pm 0.014$ & $0.149 \pm 0.015$ & $0.147 \pm 0.071$ \\
\hline & Hepatopancreas & $0.184 \pm 0.023$ & $0.230 \pm 0.068$ & $1.762 \pm 0.351^{*}$ & $0.142 \pm 0.026$ & $0.126 \pm 0.009$ \\
\hline & Intestine & $0.120 \pm 0.004$ & $0.221 \pm 0.004^{*}$ & $0.224 \pm 0.009^{*}$ & $0.192 \pm 0.007^{\star}$ & $0.223 \pm 0.007^{*}$ \\
\hline \multirow{4}{*}{$\begin{array}{l}\text { Acid phosphatase } \\
(\mu \mathrm{mole} / \mathrm{min} / \mathrm{mg} \\
\text { protein) }\end{array}$} & Haemolymph & $0.129 \pm 0.003$ & $0.122 \pm 0.003^{*}$ & $0.122 \pm 0.001^{*}$ & $0.121 \pm 0.003^{*}$ & $0.114 \pm 0.002^{*}$ \\
\hline & Muscle & $0.086 \pm 0.004$ & $0.045 \pm 0.023$ & $0.114 \pm 0.027$ & $0.116 \pm 0.018$ & $0.210 \pm 0.023$ \\
\hline & Hepatopancreas & $0.160 \pm 0.021$ & $0.175 \pm 0.024$ & $0.211 \pm 0.021$ & $0.319 \pm 0.075^{\star}$ & $0.471 \pm 0.045$ \\
\hline & Intestine & $0.220 \pm 0.001$ & $0.254 \pm 0.002^{*}$ & $0.240 \pm 0.001^{*}$ & $0.237 \pm 0.002^{*}$ & $0.225 \pm 0.001^{*}$ \\
\hline \multirow{4}{*}{$\begin{array}{l}\text { Acetylcholin-esterase } \\
(\mu \mathrm{mole} / \mathrm{min})\end{array}$} & Haemolymph & $17.99 \pm 0.353$ & $18.89 \pm 0.240$ & $18.27 \pm 0.970$ & $15.96 \pm 0.144$ & $13.71 \pm 0.120$ \\
\hline & Muscle & $0.583 \pm 0.138$ & $0.479 \pm 0.051$ & $0.427 \pm 0.089$ & $0.345 \pm 0.119$ & $0.142 \pm 0.069$ \\
\hline & Hepatopancreas & $0.591 \pm 0.155$ & $0.570 \pm 0.138$ & $0.302 \pm 0.039$ & $0.173 \pm 0.050$ & $0.101 \pm 0.036$ \\
\hline & Intestine & $9.700 \pm 0.314^{*}$ & $1.170 \pm 0.023^{*}$ & $1.000 \pm 0.064^{*}$ & $0.463 \pm 0.027^{*}$ & $0.388 \pm 0.034^{*}$ \\
\hline
\end{tabular}

Each value represent mean \pm SEM of $n=3$. ${ }^{*}$ Values were taken to be statistical significant at $P \leq 0.05$ by using analysis of variance (ANOVA). Acethylcholinesterase activity, AchE ( $\mu \mathrm{mol} \mathrm{SH}$ hydrolyzed/min $/ \mathrm{mg}) ;$ acid/alkaline phosphatase activity $(\mu \mathrm{mole}-\mathrm{p}$-nitrophenyl/min/mg); $\mathrm{protein}$ concentration $(\mathrm{mg} / \mathrm{dl})$.

\section{DISCUSSION}

The treatment of L. lybicus with varying concentrations of saponins caused inhibition of acetylcholinesterase activity in the haemolymph, muscle, hepatopancreas and intestine of the snails in a dose-dependent manner. Acetylcholinesterase (AChE) is a key enzyme in the nervous system of animals. The enzyme occurred in the outer basal lamina of nerve synapses, neuromuscular junction and in certain other tissues (Guyton and Hall, 2006). AchE is responsible for the termination of cholinergic impulses by the hydrolysis of acetylcholine released during synaptic transmission, inhibition of acetylcholinesterase thus permits accumulation of the synapses when concentration rises several folds in comparison to the normal levels, leading first to paralysis and then eventually to death (Singh and Singh, 2003). Muscle fatigue may result from impaired excitation-contraction mechanisms, neurotransmission failure or both (Kuei et al., 1990). Singh and Agarwal (1983) reported a dose dependent response of AchE as presumably due to conversion to more toxic metabolites in the body of fresh water snail (Lymnaea acuminate). The organophosphorous and carbamate pesticides, the most frequently used due to their high insecticidal activity, are acutely neurotoxic. These pesticides are effective inhibitors of the enzyme acetylcholinesterase located at neuromuscular junctions in the central and peripheral nervous system of the organisms (Walker et al., 2001). Acetylcholinesterase activity index has been widely used to indicate exposure of both vertebrate and invertebrate species to organophosphorous and carbamate pesticides (Van Erp et al., 2002) including freshwater bivalves (Moulton et al., 1996; Doran et al., 2001). Exposure of L. lybicus to E. suaveolens stem-bark saponin mixture produced a significant inhibition in AChE activity in their tissues. These responses might be useful indicators of the saponin mixture toxicity in fresh water snails. Thus, it might be suggested that the saponin mixture was neurotoxic to fresh water snails.

Decrease in the activity of muscle alkaline phosphatase was observed in the muscle of treated snails compared to the control snails. In the intestine, there was increase in the enzyme activity with increasing concentration in treated snails when compared to the control snails. However, in the haemolymph, the activity decreased with increasing concentrations of saponin except in $20 \mu \mathrm{g} / \mathrm{ml}$ treated snails in which the activity was higher than that of the control snails. In the hepatopancreas, there was an increase in the enzyme activity from $0.160 \mu \mathrm{mole} / \mathrm{min} / \mathrm{mg}$ in control snails to 0.23 and $1.76 \mu \mathrm{mole} / \mathrm{min} / \mathrm{mg}$ in 10 and $20 \mu \mathrm{g}$ treated snails respectively, while the activity in 30 and $40 \mu \mathrm{g}$ treated snails reduced to 0.142 and 0.126 $\mu \mathrm{mole} / \mathrm{min} / \mathrm{mg}$ respectively. Alkaline phosphatase breaks down ester compounds of orthophosphate acids under alkaline conditions between pH 9.2 and 9.8 (Adolph and 
Lorenz, 1981). It functions in the transport of metabolites across the membrane and also play active role in the formation of shell in mollusks as well as in glycogen metabolism (Gupta and Rao, 1974). The bioassay result showed increase in alkaline phosphatase activity in the intestine and hepatopancreas, and these two organsystems are responsible for digestion and excretion in snail. The hepatopancreas, which is the main digestive gland, consists of three cells types, the digestive cells, the crypt cells and the excretory cells (Triebskorn and Kohler, 1992). Alteration in enzyme activity can be correlated with molluscicide induced changes in the ultra structure of the cells (Triebskorn, 1991). The enhanced activity of alkaline phosphatase in the hepatopancreas might be due to activation of intracellular energy consuming process because the alkaline phosphatase facilitates breakdown of ATP to ADP and inorganic phosphate, thereby making free energy available for metabolic processes (Botham and Mayes, 2003). It was possible that the synthesis of special enzymes was involved in detoxification of activated materials and other waste metabolic products, which was used in getting rid of the molluscicide from snail's body. Immediately after poisoning with molluscicide, storage products in the cells, especially in the crop, are reduced (Triebskorn and Kunast, 1990). This is because energy was released for the activated intracellular processes. The reduction in the storage product was preceded by a proliferation of the endoplasmic reticulum which showed high alkaline phosphates activity (Triebskorn, 1989). The increase in the hepatic alkaline phosphatase activity observed in this study could be attributed to cellular damages caused by saponin mixture or a response to overcome toxicity of the saponin mixture. Reduction observed in hepatopancreas alkaline phosphatase activity in the 30 and $40 \mu \mathrm{g}$ treated snails could be due to inability of the enzyme to carry out the functions afore stated as a result of toxicity elicited by saponin mixture at higher concentration.

Acid phosphatases are hydrolytic lysosomal enzymes and are released by the lysosomes for the hydrolysis of foreign material; hence it has a role in certain detoxification functions. It is responsible for catalyzation of reactions at the beginning of intracellular digestion shortly after the fusion of primary lysosomes with digestive vacuoles or secondary lysosomes (Lodish et al., 2000). Molluscicides have been reported to induce the fusion activity due to an impact on the cytoskeleton and therefore, accelerate phosphatase catalysed primary digestive process (Triebskorn, 1991). It is known as inducible enzyme whose activity in animal tissue goes up when there is a toxic impact and the enzyme begins to counteract. Subsequently, the enzyme activity may begin to drop either as a result of having partly or fully encountered the toxin or as a result of cell damage. In the present study, acid phosphatase activity in hepatopancreas was found to decrease as saponin concentration increases, likewise in the muscle. While in the intestine, lower doses were observed to increase the enzyme activity rather than higher doses, but in the haemolymph, the activity increased with increase in concentration. The increase in acid phosphatase activity in intoxicated animals as observed in the present investigation may be due to the destruction of the lysosomal membrane which resulted in the release of the enzyme. The pronounced increase in protease activity may be due to the damage caused to the lysosomal membrane, thus permitting the leakage of lysosomal enzyme into cytosol (Sherekar and Kulkurni, 1987).

There was significant increase in haemolymph, muscle and hepatopancreas protein concentrations with increasing saponin concentrations, while the intestine protein concentration was elevated in 20 and $30 \mu \mathrm{g}$ treated snails and reduced in $40 \mu \mathrm{g}$ treated snails. The elevation observed in protein turnover could be attributed to compensating production of protein lost as a result of tissue necrosis or to meet increased demand to detoxify the ingested saponins while reduction in total protein concentration of $40 \mu \mathrm{g}$ treated snail could be attributed to inability of protein synthesizing machinery to be able to function properly.

Triterpenoids especially saponins and diterpepenoids have been reported to belong to groups of poisonous principles of African hunting poisons (Robert and Wink, 1998). Saponin bearing plants have been reported to be exclusively employed as fishing poisons, for example, plants with diterpenoid esters (Neuwinger, 1996). Pesticides are reported to considerably affect the intestine and hepatopancreas of the marine bivalves (Triebskorn, 1991). As observed from the results, these two organs were highly affected. Also, there was an indication that the toxic effect of $E$. suaveolens saponins was also manifested through the nervous system as it inhibits acetylcholine esterase activity.

Hence, the toxicity of fractionated saponin mixtures from $E$. suaveolens stem-bark towards freshwater snail (L. lybicus) was ascertained. According to Fransworth et al. (1987), for a plant to be considered as molluscicide, it should be effective in concentration of about $100 \mu \mathrm{g} / \mathrm{L}$. Therefore, E. suaveolens stem-bark saponin could be considered as potential molluscicide. This study conclusively shows that $E$. suaveolens stem- bark saponin mixture satisfied the conditions which support its promising possibilities as a potent natural candidate molluscicide. It can be used for the control of fresh water snails and pollution.

\section{REFERENCES}

Abdel-Gawad MM, El-Sayed MM, Abdel-Hameed ES (1999). Molluscicidal steroidal saponins and lipid content of Agave decipiens. Fitoterapia, 70: 371-381.

Adewunmi CO (1984). Water extract of Tetrapleura tetraptera: An effective molluscicide for the control of Schistosomiasis and fascioliasis in Nigeria. J. Anim. Prod. Res., 4: 73-84.

Adewunmi CO (1991). Plant molluscicides potential of Aridan, Tetrapleura tetrapetra for schistosomiasis control in Nigeria. Sci. 
Total Environ., 102: 21-33.

Adolph L, Lorenz R (1981). Enzyme diagnosis in hepatic disease. In: "Enzyme Diagnosis in Diseases of the heart, liver and pancreas". S. Karger AG, Basel, Switzerland, pp.81-104.

Agarwal SK, Rastogi RP (1974). Triterpenoid saponins and their genins. Phytochemistry, 13: 2623-2645.

Aiyegoro OA, Akinpelu DA, Okoh Al (2007). In vitro antibacterial potentials of the stem bark of red water tree (Erythrophleum suaveolens ). J. Biol. Sci., 7: 1233-123.

Aladesanmi AJ (2007). Tetrapleura tetraptera: Molluscicidal Activity and Chemical Constituents. Afr. J. Tradit. Complement Altern. Med., 4: 23-36.

Anon (2001). Management options for golden apple snail. Rice Technol. Bull., 33: 5-8.

Botham KM, Mayes PA (2003). Bioenergetics: The Role of ATP. In: "Harper's Illustrated Biochem, $27^{\text {th }}$ Edition. pp. 88-93.

Burkill H (1985). The Useful Plants of West Tropical Africa. Volume 3, pp. 116-120.

Clarke TE, Appleton CC, Drewes SE (1997). A semi-quantitative approach to the selection of appropriate candidate plant molluscicides: a South African application. J. Ethnopharmacol., 56: $1-13$.

Dongmo AB, Kamanji A, Achang MS, Chungag-Anye NB, Njaman D, Nguelefack TB, Nole T, Wagner H (2001). Anti-inflammatory and Anagelsic properties of the stem-bark of Erythrophelum suaveolens (Caesalpiniaceae), Guillemin and Perrottel. J. Ethnopharmacol., 77: 137-141.

Doran WJ, Cope WG, Rada RG, Sandheinrich MB (2001). Acetylcholinesterase inhibition in the three ridge mussel (Amblema plicata) by chlorpyrifos: implications for biomonitoring. Ecotoxicol. Environ. Saf., 49: 91-98.

Ellman GL, Courtney KD, Andres V, Featherstone RI (1961). A new and rapid colorimetric determination of acetylcholinesterase activity. Biochem. Pharmacol., 7: 88-90

Finney DJ (1971). Probit Analysis (3rd edition). Cambridge University Press, Cambridge, UK. p. 333

Fransworth NR, Herderson TO, Soejarto DD (1987). Plants with potential molluscicidal activity. In: Plant molluscicides. John Wiley and Sons, New York. pp. 131-204.

Gupta V, Rao G (1974). Histochemical studies on the Chroid plexus of the goat embryos III. Histochemical distribution of acid and alkaline phosphatases. Acta Histochem., 499: 60-63.

Guyton AC, Hall JE (2006). Membrane Potentials and Action Potentials I "Textbook of Medical Physiology". Eleventh Edition, Elsevier Saunders. pp. 85-88.

Kuei JH, Shadmehr R, Sieck GC (1990). Relative contribution of neurotransmission failure to diaphragm fatigue. J. Appl. Physiol., 68: 174-180.

Lemma A (1970). Laboratory and Field Evaluation of the Molluscicidal Properties of Phytolaccca Dodecandra. Bull. World Health Organ., 42: 597-612.

Lin CN, Chen HL, Yen MH (2008). Flavonoids with DNA strand Scissors activity from Rhus javanica var roxburghana. Fitoterapia, 79: 32-36.

Lodish H, Berk A, Zipursky SL, Matsudaira P, Baltimore D, Darnell J (2000). Organelles of eukaryotic cell. In: "Molecular and Cell Biology." Fourth edition W. H. Freeman, New York. pp. 730-745.

Marston A, Hostettmann K (1985). Plant Molluscicides. Phytochemistry, 24: 639-652.

Massoud AM, Habib FS (2003). The effects of Myrrh Commiphora molmol on the infected snails of Schistoso sp. and their egg masses: Effect on shedding of cercariae and on snail fecundity. J. Egypt. Soc. Parasitol., 33(2): 585-596.
Moulton CA, Fleming WJ, Purnell CE (1996). Effects of two cholinesterase inhibiting pesticides on freshwater mussels. Environ. Toxicol. Chem., 15:131-7.

Neuwinger HD (1996). In: African Ethnobotany: Poisons and Drugschemistry, pharmacology and toxicology. Chapman and Hall, London. pp 1-941.

Nwude N (1981). Some stock poisoning plants of Nigeria. J. Anim. Prod. Res., 1: 1099-122.

Nwude N, Chineme CN (1981). Toxic effects of the leaves of $E$. africanum (Harms) in sheep. Bull. Anim. Health Product. Afr., 299: $3499-3500$.

Olagunju JA, Oyedapo OO, Onasanya BA, Oshoba OO, Adebayo OO, Eweje O, Sodeinde AB (2000). Effects of isosaline extract of Tetrapleura tetraptera and Olax subscorpioides on certain biochemical parameters of albino rats. Pharm. Biol., 38: 1-4.

Oyedapo OO (1996). Studies on bioactivity of the root extract of Plumbago zeylanica. Int. J. Pharmacog, 34: 365-369.

Oyedapo OO, Amos S (1997). Further investigation into the activities of the root extract of Plumbago zeylanica. Phytother. Res., 11: 62-63.

Robert MF, Wink M (1998). Alkaloids: Biochemistry, Ecology and Medical Applications. Plenum Press, New York, pp. 397-424.

Sanni MS, Van-Etten RL (1978). An essentialcarboxylic acid group in human prostrate acid phosphatase. Biochim. Biophys. Acta, 568: 370-376.

Shacterk GL, Pollack RL (1973). A simplified method for the quantitative assay of small amount of protein in biologic material. Anal. Biochem., 51: 654-660.

Sherekar PV, Kulkarni KM (1987). Studies on the acid and alkaline phosphatase activity of methyl parathion exposed fish, Channa orientalis (Sch.). Uttar Pradesh, J. Zool., 7: 154-159.

Singh DK, Agarwal RA (1983). In vivo and in vitro studies on synergism with anticholinesterase pesticides in the snail Lymnaea acuminate. Arch. Environ. Contam. Toxicol., 12,483-487.

Singh SK, Singh A (2003). Molluscicidal and anticholinesterase activity of Alstonia scholaris plant against fresh water snail Lymnaea acuminate. Pak. J. Bio. Sci., 6: 1442-1446.

Triebskorn R (1989). Ultastructural changes in the digestive tract of Deroceras reticulum (Muller) induced by a carbamate molluscicide and metaldehyde. Malacologia, 31(1):141-156.

Triebskorn $R$ (1991). The impact of molluscicides on enzyme activities in the hepatopancreas of Deroceras reticulatum (Muller). Malacologia, 33: 255-272.

Triebskorn R Kunast C (1990). Ultrastructural changes in the digestive system of Deroceras reticulum (Mollusca, Gastropoda) induced by lethal and sublethal concentrations of the carbamate molluscicide Cleothocarb. Malacologia, 32: 87-104.

Triebskorn R Kohler HR (1992). Plasticity of the endoplasmic reticulum in three cell types of slugs poisoned by molluscicides. Protoplasma, 169 (3-4): 120-129.

van Erp S, Booth L, Gooneratne R, O'Halloran K (2002). Sublethal responses of wolf spiders (Lycosidae) to organophosphorous insecticides. Environ. Toxico., 17: 449-456.

Wagner HH, Nickel H Aynehchi Y (1984). Molluscicidal Saponins from Gundella tournefortii. Phytochem., 23: 2505-2508.

Walker CH, Hopkin SP, Sibly RM, Peakall DB (2001). Chemical Pesticides: mode of action and toxicology. In: "Principles of Ecotoxicology, Second edition. Taylor and Francis, London. pp. 245 -275 .

WHO (1985). The control of Schistosomiasis. Technical Report No. 728 , Geneva, Switzerland. pp.59-62. 